\title{
Tourism Safety And Security In The Republic Of Armenia
}

\author{
https://doi.org/10.21272/sec.4(2).14-22.2020
}

Gayane Tovmasyan, ORCID: https://orcid.org/0000-0002-4131-6322

$\mathrm{PhD}$ in Economics, Senior Researcher at "AMBERD" Research Center of the Armenian State University of Economics, Professor at the Public Administration Academy of the Republic of Armenia, The Republic of Armenia

Rubik Tovmasyan, ORCID: $\underline{\text { https://orcid.org/0000-0001-9458-9888 }}$

$\mathrm{PhD}$ in Economics, Docent at Armenian National Agrarian University, The Republic of Armenia

\begin{abstract}
The article examines the issues of security and protection of the consumers rights of tourist services. The relevance of the chosen direction of research is due to the rapid increase in the number of trips of citizens, increasing the number of threats (terrorism, civil wars, political conflicts, revolutions, epidemics, natural disasters), which are becoming more destructive and less predictable. The purpose of the study is to analyze the current position of Armenia in international rankings and indices that assess the state of tourism safety and security. The study used methods of descriptive statistics, observation, comparison and questionnaires. The information base of the study was data from international ratings and indices (Competitiveness Index in Travel and Tourism, Global Peace Index, Global Terrorism Index), as well as the results of a survey on the level of tourist satisfaction with services in Armenia. It is substantiated that the tourism industry helps to increase foreign exchange earnings, intensifies investment activities, influences the creation of new jobs, as well as promotes a positive image of the state in the international arena. The analysis of the rating positions of Armenia in different international reports allows us to say about its safety and security for travelers. The results of the survey indicate that about $87 \%$ of tourists consider Armenia a safe country and are satisfied with the quality of tourist services in this country. It is proposed to improve the national migration and visa policy, to promote Armenia as a safe destination for tourists and to develop the international cooperation in the field of tourism. The results of the study can be useful for public administration, the private sector, as well as for researchers in the tourism industry.
\end{abstract}

Keywords: tourism, safety, security, terrorism, crime, Armenia.

JEL Classification: Z3, L83, R41.

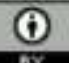

This work is licensed under a Creative Commons Attribution 4.0 International License.

Cite as: Tovmasyan, G., Tovmasyan, R. (2020). Tourism Safety And Security In The Republic Of Armenia. SocioEconomic Challenges, 4(2), 14-22. https://doi.org/10.21272/sec.4(2).14-22.2020.

(C) The Authors, 2020. This article is published with open access at Sumy State University.

\section{Introduction}

In parallel with the growth of tourism, there is a problem of ensuring the level of safety and security of tourists. Particularly in recent decades, terrorist acts, wars, political conflicts, civil wars, revolutions, epidemics, natural disasters have further sharpened the need for the safety of tourists, making it a global challenge for all countries. The level of safety and security in a given country affects the quality of tourism, the degree of satisfaction of tourists, and their decision and willingness to return to a particular destination or to recommend it to others.

The purpose of the study is to explore tourism safety and security issues in the Republic of Armenia (RA).

The structure of the article is the following: at first the literature was analyzed, then the discussion of some indexes about Armenia was done, also survey results were presented in Armenia, which shows that Armenia is considered to be a safe touristic destination. 


\section{Literature review}

In 1996 the World Tourism Organization has published the book "Tourism Safety and Security. Practical Measures for Destinations" (WTO, 1996). Accordingly, the risks involved in the following areas should be taken into account for tourism safety and security planning:

$\checkmark$ Human and institutional environment. The risks originating in the human and institutional environment appear when visitors fall victim to: common delinquency (theft, pickpocketing, assault, burglary, swindle, etc.), indiscriminate and targetted violence (such as rape) and harassment, organized crime (extorsion, white-slave trade, coercion, etc.), terrorism and unlawful interference (attacks against state institutions and state vital interests, etc.), highjacking and hostage taking, wars, social conflicts and political and religious unrest, lack of public and institutional protection and respective services.

$\checkmark$ Tourism and related sectors (transport, sports, retail trade, etc.) may be held responsible for damages to the visitors' personal security, physical integrity and economic interests as a consequence of: defects in safety standards in tourism establishments (fire, construction errors, lack of anti-seismic protection, etc.), defects in sanitation and respect for sustainability of the environment, absence of protection against unlawful interference, crime and delinquency in tourism facilities, fraud in commercial treatment, noncompliance with contracts, personnel strikes.

$\checkmark \quad$ Individual travelers may create problems for their own safety and security and for their hosts as well. The causes may be: excesses and dangerous practices of tourists in sport and leisure activities, driving, food and drink, tourists' previous health conditions which may deteriorate while travelling, visitors' conflictive or inadequate behavior with respect to resident populations or local laws, specific illicit or criminal activity (e.g. trafficking in illicit drugs), visits to dangerous areas, loss of personal effects, documents, money, etc., through inattentive actions or careless activities.

$\checkmark$ Physical and environmental risks manifest if the travelers are unaware of the natural characteristics of the destination and their effects, in particular of its flora and fauna, are not prepared from the medical viewpoint (vaccinations, prophylaxis), do not take the necessary precautions in their eating and hygienic habits, are exposed to emergencies (natural disasters, epidemics, etc.) arising from the physical environment. Physical and environmental risks are also largely personal risks, but unlike those in the preceding area which are characterized by deliberate action, the latter are due to the traveler's ignorance or passive approach to ppotential risks.

Brondoni (2016) describes tourism safety and security in the following way: tourist safety - tourists who stay in a hotel at any destination can be vulnerable to robbery, assault, rape, larceny, and fire; tourist security - an effective security system requires well-trained personnel to carry out the security procedures accordingly and to operate the security equipment properly. A comprehensive training program should include the protection of guests, the general public, and employees.

According to Mansfeld (2006) safety and security incidents will continue to occur at tourist destinations regardless of the efforts made by the private and public sector to prevent them. The majority of such incidents will have some degree of negative impact on affected destinations and their tourism industry. Though it is impossible to totally prevent the occurrence of safety and security incidents, destinations can prepare themselves for the occurrence of such incidents through crisis planning and thus reduce their negative impacts on the community, its economy, the tourism industry, and the tourists themselves. The private sector (i.e., the tourism industry) bears the major responsibility for preventing or reducing the number of safety and security incidents occurring on their own properties. The public sector and, most importantly, governments of host destinations, bear the major responsibility for ensuring a high level of security for visiting tourists.

Thus, according to Kôvári et al. (2011) security and safety has become a complex multidimensional notion with a wide range of components belonging to it: political security, public safety, health and sanitation, personal data safety, legal protection of tourists, consumer protection, safety in communication, disaster protection, environmental security, getting authentic information, quality assurance of services etc.

A study of three police authorities in large tourism destinations was conducted to understand how local law enforcement agencies view their responsibility facing the tourism industry and whether these agencies deal with crimes against tourists in a different manner than crimes against residents and the results suggest that law enforcement agencies are seriously committed to preventing and reducing crimes against tourists. To 
accomplish this, police authorities have set up special units whose sole responsibility is the protection of tourists and have trained selected personnel to deal especially with tourist matters (Pizam et al., 1997).

Another study was done to investigate the impact of crime on international tourism which showed that violent crimes are negatively associated with incoming international tourists and international tourism revenue indicating that international tourists consider the risk of victimization when choosing a location to visit (Altindag, 2014).

A recent study was done to investigate the effects of terrorism, crime, and corruption, on international tourist flows. Research results show that tourists prefer traveling to countries with similar levels of safety and security as exist in their origin country. Also, tourists from stable countries prefer traveling to countries with the same conditions, while tourists from unstable countries are more tolerant with insecurity at the destination country. Greater knowledge about the destination country reduces the negative effect of security threats on inbound tourism (Fourie et al., 2020).

According to a World Travel and Tourism Council report, 13 months is needed for tourism to recover from a terrorist attack. By comparison, tourism takes longer to overcome from disease (21 months), an environmental disaster (24 months), and political unrest (27 months) (Zillman, 2015).

Some estimations were done to find out how much tourist attack costs. According to the Time's estimate, the ISIL attack on Sousse in Tunisia produced a loss of $\$ 500$ million, a quarter of the annual revenues of Tunisian tourism. Egypt, struck in 2005 after the massacre in Sharm, the year after suffered an $8 \%$ reduction in foreign tourist arrivals. Time also calculated the recovery time from the tragedies of the last decade. New York took 34 months after 11 September 2001 to return to the pre-2001 hotel attendance rate. Madrid and London, under attack in 2004 and 2005, were faster and it took a year (Walsh, 2015).

\section{Methodology}

The purpose of the research is to explore tourism safety and security issues in the Republic of Armenia.

The object of the research is tourism sphere in Armenia. The subject of the research is tourism safety and security issues in Armenia.

In the research a variety of data are used from the Statistical Committee of the RA, The World Travel \& Tourism Council (WTTC) and other national and international organizations, medias, etc.

The main methods used in the research are as follows: analysis and synthesis, micro and macro analysis, historical analysis, comparative assessment, survey.

\section{Discussion}

In every country the relevant state authorities, tourism organizations and, of course, tourists are responsible for ensuring the safety of tourists.

According to the Law on "Tourism and tourism activities" of the RA, adopted in 2003, the state policy in the field of tourism is implemented through the protection of the rights and legal interests of tourists, as well as through measures to ensure their safety (Article 5). Article 17 of the law also states that the tourist has the right to personal security, life, health, consumer rights and property protection. According to Article 21 of the same law, tourism entities develop activities for ensuring the safety and preventing of injuries and accidents of tourists participating in tourist trips, campaigns, excursions and other events organized by them. Tourism entities are obliged to inform the relevant state authorities immediately about emergencies occurring with tourists (Law on "Tourism and tourism activities" of the RA, 2003).

In some countries there is a separate tourism police (for example, Thailand, Bangladesh, Malaysia) that deals with ensuring the safety of tourists visiting the country, detecting organized crime and protecting their legal interests.

According to the Tourism Competitiveness Report of 2019, Finland, Iceland and Oman are the safest and securest countries in the world. Armenia is in the 40th place (in 2017 it was the 34th in the report). The last 10 positions are occupied by: Jamaica, South Africa, Colombia, Pakistan, Philippines, Honduras, Venezuela, Yemen, Nigeria, Salvador (The Travel and Tourism Competitiveness Report, 2019). 
Table 1. Safety and security sub-pillar of Tourism Competitiveness Report

\begin{tabular}{|c|c|c|}
\hline $\begin{array}{c}\text { Rank in the } \\
\text { report }\end{array}$ & Country & $\begin{array}{c}\text { Score } \\
(1-7)\end{array}$ \\
\hline \multicolumn{3}{|c|}{ Countries occupying the top ten positions } \\
\hline 1 & Finland & 6.7 \\
\hline 2 & Iceland & 6.5 \\
\hline 3 & Oman & 6.5 \\
\hline 4 & Switzerland & 6.4 \\
\hline 5 & Hong Kong SAR & 6.4 \\
\hline 6 & Singapore & 6.4 \\
\hline 7 & Unitet Arab Emirates & 6.3 \\
\hline 8 & Luxembourg & 6.3 \\
\hline 9 & Portugal & 6.3 \\
\hline 10 & New Zealand & 6.3 \\
\hline \multicolumn{3}{|c|}{ Eurasian Economic Union member states } \\
\hline 40 & Armenia & 5.8 \\
\hline 63 & Kazakhstan & 5.6 \\
\hline 96 & Kyrgyz Republic & 5.2 \\
\hline 98 & Russian Federation & 5.1 \\
\hline- & Belarus & - \\
\hline \multicolumn{3}{|c|}{ Neighboring states } \\
\hline 25 & Georgia & 6.0 \\
\hline 38 & Azerbaijan & 5.9 \\
\hline 74 & Iran, Islamic Republic & 5.4 \\
\hline 125 & Turkey & 4.3 \\
\hline
\end{tabular}

Source: The Travel and Tourism Competitiveness Report 2019, p. 71.

The following are the sub-pillars of Armenia's safety and security (Travel \& Tourism Competitiveness Index, Armenia, 2019):

- Business costs of crime and violence (i.e. how much they have impacted business expenses) - 30th (5.3 points),

- Reliability of Police Services - 65th (4.6 points),

- Business costs of terrorism - 28th (5.7 points),

- Index of terrorism incidence - 62nd (7.0 points)

- Homicide rate (100,000 population) - 71st (3.0 points).

How do tourists get information about the safety of a destination before traveling? Of course, possible sources of information could be travel agencies, embassies of the country, and of course the Internet. Often, when reading other tourists' impressions on different sites, people get an idea of the degree of security of different countries, which can also be deceptive. Tourists can get information about security by studying the statistics of crime, terrorism in the country of visit.

Countries where the level of terrorism is high may be considered more dangerous for tourists. Major terrorist acts include: massacre of 62 tourists at Deir al-Bahari archaeological site in Luxor, Egypt by Islamic terrorist groups, in 200588 people were killed in Sharm El Sheikh bombings, in 20198 blasts occurred during Easter liturgies in churches and in hotels in Sri Lanka's Colombo, Negombo and Batikala on April 21, killing more than 320 people (including 39 tourists) and wounding 520 (including 28 tourists) (Sri Lanka blasts: Death toll reaches 321, 2019). At the same time, it is predicted that the scenario of terror in Sri Lanka may be repeated elsewhere, where the tourist flow is high, for example in India, Maldives, Kenya and Tanzania (Media. Like in Sri Lanka, terrorism is possible also in India and Maldives, 2019).

In 2018 the number of terrorist acts in the world was 9600 against 17,000 in 2014, killing more than 22,980 people (in 2014 - more than 45,000 people) (Global Terrorism in 2018). In recent years, 60\% of terrorist acts took place in five countries - Afghanistan, India, Iraq, Nigeria, Pakistan (Country Reports on Terrorism Statistical Annex, n.d.), and 87\% of terrorist acts have been done in 10 countries - Afghanistan, Nigeria, Iraq, Syria, Somalia, Pakistan, Pakistan. Congo, India, Yemen, and 13\% in the rest of the world (Global Terrorism Index, 2019, p. 13). 
The Institute for Economics \& Peace (IEP) publishes the Global Terrorism Index and the 7th publication was in 2019. It is a comprehensive study that analyzes the impact of terrorism on 163 countries, comprising $99.7 \%$ of the world's population. The index is rated on a scale of 0-10 (from no impact to very high) by measuring the total number of terrorist incidents in a given year, total number of fatalities caused by terrorists in a given year, total number of injuries caused by terrorists in a given year, and the total property damage from terrorist incidents in a given year. The leaders of the Global Terrorism Index 2019 were Afghanistan, Iraq, Nigeria, and Armenia was in the 94th position (Global Terrorism Index, 2019, p. 13).

Table 2. Some Indicators of Global Terrorism Index 2019

\begin{tabular}{|c|l|c|}
\hline \multicolumn{1}{|c|}{ Country } & $\begin{array}{c}\text { Score } \\
(\mathbf{0 - 1 0})\end{array}$ \\
\hline \multicolumn{1}{|c|}{ Countries occupying the top ten positions } & $\mathbf{9 . 6 0 3}$ \\
\hline $\mathbf{1}$ & Afghanistan & $\mathbf{9 . 2 4 1}$ \\
\hline $\mathbf{2}$ & Iraq & $\mathbf{8 . 5 9 7}$ \\
\hline $\mathbf{3}$ & Nigeria & 8.006 \\
\hline 4 & Syria & 7.889 \\
\hline 5 & Pakistan & 7.8 \\
\hline 6 & Somalia & 7.518 \\
\hline 7 & India & 7.259 \\
\hline 8 & Yemen & 7.137 \\
\hline 9 & Philippines & 7.039 \\
\hline 10 & Democratic Republic of the Congo & \\
\hline $\mathbf{9}$ & Eurasian Economic Union member states & $\mathbf{1 . 1 7 3}$ \\
\hline $\mathbf{9 4}$ & Armenia & 1.566 \\
\hline 85 & Kazakhstan & 1.467 \\
\hline 37 & Kyrgyz Republic & 4.9 \\
\hline- & Russian Federation & - \\
\hline & Belarus & 1.335 \\
\hline 90 & Georgia & 0.698 \\
\hline 103 & Azerbaijan & 4.717 \\
\hline 39 & Iran, Islamic Republic & 6.533 \\
\hline 16 & Turkey & \\
\hline
\end{tabular}

Source: Global Terrorism Index 2019, pp. 8-9.

According to the report, in 2018 one terrorist act was committed in Armenia, but security forces arrested suicide bomber, no casualties were (Global Terrorism Index 2019, p. 42).

The Institute of Economics and Peace also publishes the Global Peace Index, which includes the following indices: ongoing domestic and international conflict domain, societal safety and security domain, militarisation domain, rating at 1-5 (from very high to very low). The most peaceful countries are Iceland, New Zealand, Portugal. Armenia ranks 118th out of 163 countries (Global Peace Index, 2019).

Table 3. Some indicators of Global Peace Index 2019

\begin{tabular}{|l|l|r|}
\hline Rank & Country & Score (0-10) \\
\hline Countries occupying the top ten positions & $\mathbf{1 . 0 7 2}$ \\
\hline $\mathbf{1}$ & Iceland & $\mathbf{1 . 2 2 1}$ \\
\hline $\mathbf{2}$ & New Zealand & $\mathbf{1 . 2 7 4}$ \\
\hline 4 & Portugal & 1.291 \\
\hline 5 & Austria & 1.316 \\
\hline 6 & Denmark & 1.327 \\
\hline 7 & Canada & 1.347 \\
\hline 8 & Singapore & 1.355 \\
\hline 9 & Slovenia & 1.369 \\
\hline 10 & Japan & 1.375 \\
\hline $\mathbf{1 1 8}$ & Czech Republic & $\mathbf{2 . 2 9 4}$ \\
\hline 64 & Armenia & 1.932 \\
\hline 95 & Kazakhstan & 2.105 \\
\hline 154 & Kyrgyz Republic & 3.093 \\
\hline 97 & Russian Federation & 2.115 \\
\hline
\end{tabular}


Table 3 (cont.). Some indicators of Global Peace Index 2019

\begin{tabular}{|l|l|r|}
\hline Rank & Country & Score (0-10) \\
\hline Eurasian Economic Union member states & \\
\hline Neighboring states & 2.122 \\
\hline 99 & Georgia & 2.425 \\
\hline 130 & Azerbaijan & 2.542 \\
\hline 139 & Iran, Islamic Republic & 3.015 \\
\hline 152 & Turkey & \\
\hline
\end{tabular}

Source: Global Peace Index 2019, pp. 8-9.

Armenia was the 137th out of 163 countries with 2,437 score in terms of ongoing domestic and international conflict domain, the 65th with 2,357 score in terms of societal safety and security domain, and the 104th with 1,942 score in terms of militarization domain (Global Peace Index 2019, pp. 96-98).

Why safety and security are important in tourism? Tourists can become victims of terrorism, and sometimes terrorists enter the country either as tourists or as migrants. The issue here is the problem of facilitating/liberalizing appropriate migration policies or tourist entry regimes.

A foreign citizen may enter Armenia on the basis of a valid passport, entry visa or residence document and with the permission of the border control authority.

Types of entry visas to Armenia are: visitor visas, official visas, diplomatic visas, transit visas (Types of Armenian Visas, n.d.). According to Article 8 of the "Law of the RA on Foreigners", the issuance of a visa to a foreigner (extension of time) is denied, the visa is revoked, or entry is prohibited if:

a) he was expelled from the territory of the Republic of Armenia or deprived from residence status, and three years have not elapsed since the decision on deportation or deprivation of residence took effect;

b) he has been subjected to administrative liability for a violation of this law and has failed to fulfill his obligation under the administrative act, unless one year has elapsed since the date of his administrative liability;

c) there is reliable evidence that he carries out, participates, organizes or is a member of an organization which purpose is:

- cause damage to the RA state security, overthrow the constitutional order, weaken the defense capability,

- carry out terrorist activities,

- transfer illegally weapons, explosives, radioactive substances, drugs, psychotropic substances across the border (without appropriate authorization), or

- has trafficked in human beings and / or done illegal border crossings .

d) he / she has an infectious disease that endangers the health of the population, except when he / she enters the RA to treat such a disease. The list of those infectious diseases is defined by the Government of the RA,

e) he / she has submitted false information about himself / herself or has not provided the required documents or there is evidence that his / her entry or stay in the RA has a purpose other than that stated, or

f) there are other serious and justified threats to the RA state security or public order.

The issuance of a visa to a foreigner (extension of time) may be refused, the visa granted may be revoked or entry to the RA denied if he or she has been convicted of committing a grave or particularly serious crime under the Criminal Code of the Republic of Armenia and conviction has not been resolved (Law of the Republic of Armenia on Foreigners, article 8, 2006).

Citizens of countries for which a visa-free entry is established may stay in Armenia for a maximum of 180 days per year.

Citizens of 45 countries are unilaterally exempted from the visa requirement of the Republic of Armenia (List of countries whose citizens with all types of passports are unilaterally exempt from the requirement to obtain a visa to enter the Republic of Armenia, n.d.). Citizens of 63 States are exempt from the visa requirement by mutual agreement, including only Azerbaijan, Albania, Argentina, Belarus, Brazil, Iran, Hong Kong, 
Kazakhstan, Kyrgyzstan, Macao, Russia, Moldova, Uzbekistan, Moldova, Georgia, Moldova, Uzbekistan, Ukraine, Uruguay whose citizens for all types of passports are not required to obtain a visa (List of countries, with which Armenia has a visa-free regime according to bilateral and multilateral agreements, n.d.).

The following residence permits are defined for foreigners in the RA: temporary, permanent, special (Law of the Republic of Armenia on Foreigners, article 14, 2006).

In 2019 the number of entries into Armenia was 4319618, 55\% of which were with documents of the RA (in 2018 the number of entries into Armenia was $3757168,57 \%$ of which were with documents of the RA (Socialeconomic situation in January -December, 2019, p. 152).

The number of incoming tourists was 1894377 in 2019, compared to 1651782 in 2018 (Social-economic situation in January, 2020, p. 112).

According to the statistics in the second half of 2019 the number of asylum seekers in the RA was 166, of which 77 were from Iran, 27 from Syria, 17 from Iraq.

In 2019 second half, 75 people were granted refugee status ( 29 from Iran, 24 from Syria, 12 from Iraq), 7986 people were granted residency status (5345 - temporary, 2079 - permanent, 562 - special), of which 1835 were from India, 1327 - from Russian Federation, 1254 - from Iran, 418 - from Syria, 363 - from Iraq, 318 from USA, 312 - from Ukraine, 242 - from Georgia, 231 - from Lebanon, 184 - from China (Social-economic situation in January-December, 2019, p. 153-154)

Of course, visa liberalization is more important for tourism development. But on the other hand, it may also cause problems. In recent years, the number of foreigners who have been granted the RA residency status has also increased, especially the number of Indian citizens (for example, 938 in 2017, 1835 in 2019).

For finding out how tourists rate safety and security in Armenia, a survey was conducted among 385 tourists in different touristic destinations in Armenia during 2018. Among many questions the tourists were also asked to rate the level of their personal safety and security during the stay in Armenia.

$60 \%$ of participants were very satisfied, $27 \%$ were satisfied, $5.5 \%$ were somehow satisfied, $1.5 \%$ were dissatisfied, $6 \%$ were very dissatisfied with the level of personal safety and security during the stay in Armenia.

Tourists were asked to evaluate the factors according to their level of perception (Very dissatisfied-1, Dissatisfied-2, Somewhat satisfied-3, Satisfied-4, Very satisfied-5), expectations (Very low-1, Low-2, Medium-3, High-4, Very high-5) and importance for them (Not important at all-1, Not important-2, Of medium importance-3, Important-4, Very important-5). The survey results were already analyzed in another research paper (Tovmasyan, 2019).

Table 4. Evaluations of some services by tourists

\begin{tabular}{|l|c|c|c|c|c|}
\hline \multicolumn{1}{|c|}{ Question } & $\begin{array}{c}\text { Your } \\
\text { satisfaction } \\
\text { level }\end{array}$ & $\begin{array}{c}\text { The level of } \\
\text { your } \\
\text { expectations }\end{array}$ & $\begin{array}{c}\text { Importance } \\
\text { of the factor } \\
\text { for you }\end{array}$ & $\begin{array}{c}\text { (Satisfaction- } \\
\text { Expectations) }\end{array}$ & $\begin{array}{c}\text { Weighted } \\
\text { index } \\
\text { (Satisfaction- } \\
\text { Expectations) } \\
\text { *Importance }\end{array}$ \\
\hline $\begin{array}{l}\text { The level of your personal safety and security } \\
\text { during your stay in Armenia }\end{array}$ & 4.25 & 4.16 & 4.52 & 0.09 & 0.41 \\
\hline The time you spend in Armenia & 4.34 & 4.17 & 4.50 & 0.16 & 0.72 \\
\hline
\end{tabular}

Source: Compiled by the author based on the survey results.

At the beginning of 2020 coronavirus disease epidemic (Covid-19) spread worldwide causing many problems for tourists and tourism destinations. On 6 March, 2020, UNWTO has revised its 2020 prospects for international tourist arrivals to a negative growth of $1 \%$ to $3 \%$, translating into an estimated loss of US\$ 30 to 50 billion in international tourism receipts. Prior to the COVID-19 outbreak, UNWTO predicted a positive growth of $3 \%$ to $4 \%$ for this year (UNWTO, 2020). In many countries, as well as in Armenia, flights are cancelled, hotels and restaurants are closed, and for safety and security issues people stay at home, do not go to work, to school, and of course do not travel. This of course will have a negative impact on the tourism sphere globally. 


\section{Conclusion}

Providing tourism safety and security is very important for destinations. Tourists tend to travel securer and safer places. This article analyzed tourism safety and security issues in Armenia. Although Armenia is considered a safe and secure country, there are no terrorist acts, but careful migration and visa policies should be pursued. Terrorism is more dangerous in countries where there are more migrants. In 2019 Armenia was the 94th in the Global Terrorism Report, the 118th in the Global Peace Report, and 40th in the Tourism Competitiveness Report's Safety and Security sub-pillar. Although Armenia's position in the first two reports is not very favorable, but in terms of tourism, we can actually consider Armenia as a safe and secure country, which is highly appreciated by tourists. On the whole, on potential tourists may have a negative impact Armenia's closed borders with the two neighboring states and the Nagorno-Karabakh conflict, which may be mistaken for some tourists to think that there is a state of war here, but upon arriving in Armenia, they realize that the country is safe and secure. Therefore, it is necessary to present Armenia abroad as a safe and secure country with rich history and culture and tourist attractions.

\section{References}

1. Altindag, D.T. (2014). Crime and International Tourism. Journal of Labor Research, 35, 1-14 https://doi.org/10.1007/s12122-014-9174-8. (Accessed: 20.03.2020)

2. Brondoni, S. M. (2016). Global Tourism and Terrorism. Safety and Security Management, Symphonya. Emerging Issues in Management, 2, 7-16. http://dx.doi.org/10.4468/2016.2.02brondoni, (Accessed: 20.03.2020)

3. Country Reports on Terrorism - Statistical Annex, https://www.start.umd.edu/research-projects/countryreports-terrorism-statistical-annex. (Accessed: 20.03.2020)

4. Fourie J., Rosselló-Nadal J., Santana-Gallego M., (2020). Fatal Attraction: How Security Threats Hurt Tourism, Journal of travel research, 59(2), 209-219. https://doi.org/10.1177/0047287519826208, (Accessed: 20.03.2020)

5. Global Terrorism

in 2018 , https://www.start.umd.edu/sites/default/files/publications/local attachments/START GTD Terrorismin 20180verview FactSheet Oct2019.pdf. (Accessed: 20.03.2020)

6. Institute for Economics \& Peace. Global Peace Index 2019: Measuring Peace in a Complex World, Sydney, June 2019. http://visionofhumanity.org/app/uploads/2019/06/GPI-2019-web003.pdf. (Accessed: 20.03.2020)

7. Institute for Economics \& Peace. Global Terrorism Index 2019: Measuring the Impact of Terrorism, Sydney, November 2019, http://visionofhumanity.org/app/uploads/2019/11/GTI-2019web.pdf. (Accessed: 20.03.2020)

8. Kôvári I., Zimányi K., (2011). Safety and security in the age of global tourism (The changing role and conception of Safety and Security in Tourism), Applied Studies in Agribusiness and Commerce APSTRACT Agroinform Publishing House, Budapest, pp. 59-61, 10.19041/Apstract/2011/3-4/10, (Accessed: 20.03.2020)

9. Law of the Republic of Armenia on Foreigners, adopted in 2006, https://www.arlis.am/DocumentView.aspx?docid=99037. (Accessed: 20.03.2020)

10. Law on "Tourism and tourism activities" of the RA, adopted in 2003, https://www.arlis.am/DocumentView.aspx?DocID=64659. (Accessed: 20.03.2020)

11. List of countries whose citizens with all types of passports are unilaterally exempt from the requirement to obtain a visa to enter the Republic of Armenia, https://www.mfa.am/en/visafreelist. (Accessed: 20.03.2020)

12. List of countries, with which Armenia has a visa-free regime according to bilateral and multilateral agreements, https://www.mfa.am/en/whoneedvisa. (Accessed: 20.03.2020)

13. Mansfeld Y., Pizam A. (2006). Tourism, Security and Safety, From Theory to Practice, ISBN 978-0-75067898-8, 376 p. https://www.sciencedirect.com/book/9780750678988/tourism-security-and-safety, (Accessed: 20.03.2020)

14. Media. Like in Sri Lanka, terrorism is possible also in India and Maldives, 2019, http://www.panarmenian.net/arm/news/268199/\%D5\%BE, (Accessed: 20.03.2020)

15. Pizam A., Tarlow P. E., Bloom J. (1997) Making Tourists Feel Safe: Whose Responsibility is it? Journal of travel research, 36(1), 23-28, https://doi.org/10.1177/004728759703600104, (Accessed: 20.03.2020) 
16. Sri Lanka blasts: Death toll reaches 321, 2019, https://news.am/arm/news/508805.html. (Accessed: 20.03.2020) situation in January-December,

2019 ,

$\mathrm{p}$

152 , https://www.armstat.am/file/article/sv 12 19a 520.pdf. (Accessed: 20.03.2020)

18. Social-economic situation in January, 2020, https://www.armstat.am/file/article/sv_01_20a_421.pdf. (Accessed: 20.03.2020)

19. Social-economic situation in January-December, 2019, https://www.armstat.am/file/article/sv_12_19a_520.pdf. (Accessed: 20.03.2020)

20. The Travel and Tourism Competitiveness Report 2019, p. 71, http://www3.weforum.org/docs/WEF_TTCR_2019.pdf. (Accessed: 20.03.2020)

21. The Travel \& Tourism Competitiveness Index 2019 edition, Armenia, http://reports. weforum.org/pdf/ttci2019/WEF_TTCI_2019_Profile_ARM.pdf. (Accessed: 20.03.2020)

22. Tovmasyan, G. (2019) Assessment of Tourist Satisfaction Index: Evidence from Armenia. Marketing and Management of Innovations, 3, 22-32. http://doi.org/10.21272/mmi.2019.3-02. (Accessed: 20.03.2020)

23. Types of Armenian Visas, https://www.mfa.am/en/visa. (Accessed: 20.03.2020)

24. UNWTO (2020), COVID-19: UNWTO calls on tourism to be part of recovery plans, https://unwto.org/news/covid-19-unwto-calls-on-tourism-to-be-part-of-recovery-plans. $\quad$ (Accessed: 20.03.2020)

25. Walsh, D. (2015). Tunisia Beach Terror Attack will Cost Tour Operator up to €40m, The Times, August 14, https://www.thetimes.co.uk/article/tunisia-beach-terror-attack-will-cost-tour-operator-up-toeuro40m-kfjd6xkmp5b, (Accessed: 20.03.2020)

26. WTO, (1996) Tourist Safety and Security: Practical Measures for Destinations, p. 17-18, https://www.eunwto.org/doi/book/10.18111/9789284401529. (Accessed: 20.03.2020)

27. Zillman, C. (2015). Terrorism's Effect on Tourism Doesn't Last Very Long, Fortune, November 30., https://fortune.com/2015/11/30/terrorism-tourism-paris/. (Accessed: 20.03.2020) 